\title{
Problems to Be Faced Measuring Real Income per Capita: The Case of Mexico
}

\author{
Carlos Encinas-Ferrer \\ Faculty of Business, Universidad De La Salle Bajio, Leon, Mexico \\ Email: cencinas@delasalle.edu.mx
}

Received 23 February 2016; accepted 28 March 2016; published 31 March 2016

Copyright (C) 2016 by author and Scientific Research Publishing Inc.

This work is licensed under the Creative Commons Attribution International License (CC BY). http://creativecommons.org/licenses/by/4.0/

(c) (i) Open Access

\section{Abstract}

The last 35 years have been characterized, worldwide, for lack of economic growth and increasing inequality in income distribution and its concentration. This has resulted in increased poverty and falling purchasing power of the middle classes, which has become the most serious problem with which we enter the twenty-first century. Mexico has been no exception. This article covers the first part of the research I'm doing in the 9th. Researchers call for 2015-2016 of the De La Salle University Bajio in Leon, Mexico. In the second part I will discuss inequality in income deciles in which is statistically divided our population and the way in which the concentration of income in fewer hands is affecting the market performance. This research has required having historical series covering the last 57 years of economic and population growth in Mexico. Measure the evolution of gross domestic product (GDP) from the beginning of the presidential terms from 1959 to 2015. It has been problematic since in Mexico there are not series covering the entire period. $I$ had to go to the World Bank data (WB) which provides them from 1960. We found discrepancies in GDP series between those of WB, International Monetary Fund (IMF), United Nations Organization (UNO) and the National Institute of Geography and Statistics (INEGI) from Mexico. The second difficulty appeared in the series of the population of our country. There are also discrepancies between census data and estimates of the same INEGI. Moreover, the series of WB and Penn World Table (PWT) also show differences between them. Converting the results of real GDP per capita to dollars had no difficulty due to information from the Mexican Central Bank (BM). The conversionto international dollars as estimated by the purchasing power parity (PPP) was obtained from PWT 8.1.

\section{Keywords}

Gross Domestic Product, Real Gross Domestic Product, Gross Domestic Product per Capita in Pesos and Dollars 


\section{Introduction}

The world wide lack of economic growth and the increasing inequality in the distribution of income have become two of the most serious economic and social problems as we move more into the twenty-first century.

While inequality has existed historically and is intrinsic to the capitalist system of production, it had been mitigate by the instruments of economic policy developed by John Maynard Keynes and other economists in the thirties and forties of the twentieth century. By unemployment insurance, public health care, public education, housing programs, direct transfers to the neediest, etc., the state could influence a better income distribution. This policy promoted the so-called "welfare state" and through it, wider and dynamic domestic markets. The resources used for these programs return to the firms that produce goods and services through the sale thereof.

In the early eighties of last century came to power political groups related to a current of thought known as neoliberalism, frontally opposed to state intervention in the economy and which presented the market as the perfect mechanism to allocate resources. It was a sector that had its origins in the most conservative interpretation of the neoclassical school that had established their dominance over the teaching of economics between 1880and 1910 and lost influence during the decades of the twenties and thirties of the twentieth century due to World War One, the Mexicanr evolution, the Russian revolution and the great depression that began in 1929 and will last until 1933. All these phenomena, a result of major contradictions with in the production system, opened the doors to an economic thinking called Keynesianism inspired by the thoughts of the English economist John Maynard Keynes.

Paul Krugman wrote in 1992 [1] "After three decades during which the income distribution had remained relativelys table, wages and incomes rapidly became more unequal.” This issue has caught my attention for several years. A product of that interest was the article I wrote in 2009 in the Journal Problems of Development [2] and in which I showed statistically that it was from1980that growing inequality began to spread in the United States of America (USA). Remember that it was with the governments of Margaret Thatcher (1979-1990), in the UK, and Ronald Reagan (1981-1989), in the US that neoliberalism begins to spread virtually worldwide.

What I mean by neoliberalism? Let me follow with some modifications, on a text I wrote some years ago [3]: I understand by neoliberalism a doctrine of economic policy that uses a series of arguments to impose the paradigm of non-intervention of the state in the economy and the disappearance of any transferor subsidy seeking to redistribute income among the population. Uses as a flag the free market (whatever that term means) as the only guarantee to achieve balance and economic growth. As an inherent contradiction of this doctrine, but as a logical result of its implementation, the beneficiaries of its measures have been oligopolies and transnational monopolies, natural enemies of free competition.

Neoliberalism has demonized the State as a lousy manager omitting something that is unquestionable: companies that show a shorter life are created by the private sector and the most catastrophic banking and corporations failures are found mainly among those in which the private business sector dominates (Enron, American Home Mortgage, General Motors and Lehman Brothers are just a few examples to which we can add many more).

If the result of the application of neoliberal policies has led in recent decades to an increasingly unequal income distribution reflected in its excessive accumulation of at the top of society, accumulation that in poor countries has been accompanied by an increase in poverty and in developed ones of the impoverishment of the middle classes, we can understand the interest of a growing number of researchers, mine among them, to focus, first in its measurement, and later in its effects on market functioning and its reflection in this global crisis that since 2001 has settled in the World and far from lessening, is increasing in severity year after year.

\section{Measuring Gross Domestic Product (GDP) per Capita}

To understand the problem of the concentration of income we need to start looking at the various ways that we have to measure it, first and foremost as a national average. To do this we start with two variables: Gross Domestic Product, GDP by their initials, and the population of a country (POP).

The initial estimate of the standard of living of a country first requires the knowledge of the amount of goods and services produced within its borders in a year. Its measurement is not simple and requires sophisticated statistical calculations in which estimations play an essential role due to the practical impossibility of having the actual figures. One of the main problems, for example, is the high percentage of the economically active population working, as in the case of Mexico in the informal sector which according to information provided by 
the National Institute of Statistics and Geography (INEGI) [4], from the National Survey of Occupation and Employment; Labor informality. Informal quarterly rates for the quarter July-September 2015; the rate of informal employment was $57.8 \%$.

\subsection{Nominal GDP}

GDP is measured at first instance in national currency units at current prices. For example, Mexico's GDP in 2014 was, according to the National Institute of Geography and Statistics (INEGI) of \$17,251,611.6 million Pesos. If we, for example, look for the same data at the United Nations Statistics Division [5] we find other amount, $\$ 17,009,379$. Why these differences? We have to note, as I previously mentioned, that the GDP figures are estimates and, therefore, an approach whose calculation is very complicated and requires many years of experience and improvements.

Statistics departments of international organizations such as the World Bank (WB) [6], the United Nations Organization (UNO), the International Monetary Fund (IMF) [7] and others, perform their own estimates but always tend to coincide with a margin of difference with the national information provider of each country, in the case of Mexico: INEGI. As we can see in Table 1, the conversion of series on the base 2008 was accepted and shared by the departments of statistics from the World Bank and the IMF until 2005. The IMF continues on this tune until 2001, but WB changes and share UNO figures until 2011.

Table 1. Mexico's GDP in local currency and current prices (Millions of Pesos). Source: Own elaboration with data from World Bank (WB), International Monetary Fund (IMF), United Nations Organization (UNO) and INEGI.

\begin{tabular}{|c|c|c|c|c|}
\hline Year & World Bank & IMF & UNO & INEGI \\
\hline 1993 & $1,570,147$ & $1,570,147$ & $1,402,748$ & $1,570,147$ \\
\hline 1994 & $1,779,754$ & $1,779,754$ & $1,585,840$ & $1,779,754$ \\
\hline 1995 & $2,206,943$ & $2,206,943$ & $2,051,332$ & $2,206,943$ \\
\hline 1996 & $3,020,033$ & $3,020,033$ & $2,820,217$ & $3,020,033$ \\
\hline 1997 & $3,805,272$ & $3,805,272$ & $3,544,597$ & $3,805,272$ \\
\hline 1998 & 4,586,366 & 4,586,366 & $4,295,078$ & 4,586,366 \\
\hline 1999 & $5,539,866$ & $5,539,866$ & $5,130,760$ & $5,539,866$ \\
\hline 2000 & $6,464,302$ & $6,464,302$ & $6,132,389$ & $6,464,302$ \\
\hline 2001 & $6,770,398$ & $6,770,398$ & $6,487,465$ & $6,770,398$ \\
\hline 2002 & $7,160,499$ & $7,160,499$ & 6,993,815 & $7,160,499$ \\
\hline 2003 & $7,695,624$ & $7,695,624$ & $7,696,035$ & 7,695,624 \\
\hline 2004 & $8,693,240$ & $8,693,240$ & $8,690,254$ & $8,693,240$ \\
\hline 2005 & $9,441,350$ & $9,441,350$ & $9,424,602$ & $9,441,350$ \\
\hline 2006 & $10,520,793$ & $10,538,115$ & $10,520,793$ & $10,538,115$ \\
\hline 2007 & $11,399,472$ & $11,403,263$ & $11,399,472$ & $11,403,263$ \\
\hline 2008 & $12,256,864$ & $12,256,863$ & $12,256,864$ & $12,256,863$ \\
\hline 2009 & $12,072,542$ & $12,093,890$ & $12,072,542$ & $12,093,890$ \\
\hline 2010 & $13,266,858$ & $13,282,061$ & $13,266,858$ & $13,282,061$ \\
\hline 2011 & $14,527,337$ & $14,550,014$ & $14,527,337$ & $14,550,014$ \\
\hline 2012 & $15,599,271$ & $15,627,713$ & $15,600,077$ & $15,626,907$ \\
\hline 2013 & $16,077,059$ & $16,121,442$ & $16,082,510$ & $16,116,130$ \\
\hline 2014 & $17,209,663$ & $17,050,555$ & $17,009,379$ & $17,251,612$ \\
\hline
\end{tabular}


From 2012 and to this day none of the figures matches. This shows the lack of confidence of statistical departments of international organizations in the way that INEGI has established accounting of GDP in the base 2008. We recently heard criticism to INEGI from prominent members of the Ministry of Finance of Mexico (SHCP) to the effect that the data of GDP provided by the Institute were inaccurate.

Of these discrepancies comes the need to establish a system of calculating GDP in which we compare the way we are conducting in Mexico our estimates with those of major international organizations.

Informality and lack of access to various regions of the country where in security prevents deprives us certainly to establish with certainty how the economy is behaving but there are statistical tools that can approach us to a figure that is internationally shared.

I have based my calculations in this article on the figures provided by INEGI.

\subsection{Real GDP}

In nominal GDP figures there is an element that distorts the reality which is inflation. From year to year the prices of goods and services produced vary and we need to eliminate that variation of prices in order to have a figure that is as close as possible to the actually produced physical units, what we call deflate. For this we need to establish a base year from which we make comparisons on what we call constant prices.

To adjust the real prices of GDP we use the so-called GDP deflator built on the basis of price changes of all final goods domestically produced and consumed annually in a country. Unlike the CPI, it is not calculated on the basis of a fixed basket and does not include changes in import prices.

Statistics Departments provide us with this deflator index which they use for their estimations of real GDP. In the case of Mexico the latest figures are calculated on base year 2008 and so do the World institutions data I am consulting.

In Table 2 we can see that the discrepancies we saw in current prices are less significant when numbers are deflated, something very difficult to explain.

Table 2. Mexico’s Real GDP in local currency and constant 2008 prices (Millions of Pesos). Source: Own elaboration with data from WB, IMF, UNO and INEGI.

\begin{tabular}{lcccc}
\hline Year & World Bank & IMF & UNO & INEGI \\
\hline $\mathbf{1 9 9 3}$ & $8,132,915$ & $8,132,915$ & $7,958,681$ & $8,132,915$ \\
$\mathbf{1 9 9 4}$ & $8,517,387$ & $8,517,387$ & $8,310,083$ & $8,517,387$ \\
$\mathbf{1 9 9 5}$ & $8,026,898$ & $8,026,898$ & $7,797,601$ & $8,026,897$ \\
$\mathbf{1 9 9 6}$ & $8,498,459$ & $8,498,459$ & $8,199,436$ & $9,090,49,459$ \\
$\mathbf{1 9 9 7}$ & $9,090,197$ & $9,090,197$ & $9,517,604$ \\
$\mathbf{1 9 9 8}$ & $9,517,604$ & $9,517,604$ & $8,754,699$ & $9,771,440$ \\
$\mathbf{1 9 9 9}$ & $9,771,440$ & $9,771,440$ & $9,195,094$ & $10,288,982$ \\
$\mathbf{2 0 0 0}$ & $10,288,982$ & $10,288,982$ & $10,226,682$ \\
$\mathbf{2 0 0 1}$ & $10,226,683$ & $10,226,683$ & $10,540,539$ & $10,240,173$ \\
$\mathbf{2 0 0 2}$ & $10,240,173$ & $10,240,173$ & $10,169,354$ & $10,385,857$ \\
$\mathbf{2 0 0 3}$ & $10,385,857$ & $10,385,857$ & $10,166,016$ & $10,832,004$ \\
$\mathbf{2 0 0 4}$ & $10,832,004$ & $10,832,004$ & $10,244,492$ & $11,160,493$ \\
$\mathbf{2 0 0 5}$ & $11,160,493$ & $11,160,493$ & $10,386,917$ & $11,718,672$ \\
$\mathbf{2 0 0 6}$ & $11,712,325$ & $11,718,672$ & $10,824,202$ & $12,087,602$ \\
$\mathbf{2 0 0 7}$ & $12,090,028$ & $12,087,602$ & $11,157,112$ & $12,256,863$ \\
$\mathbf{2 0 0 8}$ & $12,256,864$ & $12,256,864$ & $11,712,325$ & $11,680,749$ \\
$\mathbf{2 0 0 9}$ & $11,675,438$ & $11,680,750$ & $12,090,028$ & $12,277,659$ \\
$\mathbf{2 0 1 0}$ & $12,282,459$ & $12,277,659$ & $12,256,864$ & $12,774,243$ \\
$\mathbf{2 0 1 1}$ & $12,763,880$ & $12,774,243$ & $11,675,438$ & $13,287,534$ \\
$\mathbf{2 0 1 2}$ & $13,279,399$ & $13,286,154$ & $12,282,459$ & $13,466,300$ \\
$\mathbf{2 0 1 3}$ & $13,464,633$ & $13,470,942$ & $12,763,880$ & $13,769,334$ \\
$\mathbf{2 0 1 4}$ & $13,765,001$ & $13,757,167$ & $13,278,019$ & $13,759,379$ \\
\hline
\end{tabular}


In Figure 1 we see series presented, nominal and real, and their point of intersection, the base year 2008 data from INEGI.

Statistical handling allows us to present the percentage changes in the figures of the previous graph what gives us a better idea of the actual behavior of the economy in the period studied. In the chart below we see how inflation distorts reality and the reason that leads us to base our investigations on data where inflation has been eliminated.

That procedure allows GDP figures to be as close as possible to the real physical growth of domestic production. In Figure 2 we see that the slope of GDP at constant prices—in deflated figures to the base year 2008-is much lower than the one of current prices and shows the real growth of our economy that in 27 years has only been able to increase $74 \%$ while GDP at current prices increased $1064.5 \%$ in the same period, due to the high cumulative inflation especially during the first 10 years.

I pointed out at the beginning of this paper that since the implementation of neoliberal policies by the governments of the UK and US the growth of the economy of those nations slowed down.

When we do the same analysis for Mexico, we face the problem that the longest series of annual GDP data from Aparicio Cabrera, Abraham (2011) [8]. INEGI (Bank Information Statistics-BIE-series) discontinued this series from 1900 to 1995. Aparicio who was the author of the mentioned series, continued them up to 2010. From that last year we don't have a complete one. There is no equivalence between the base series of1970, 1983, 2003 and 2008. This is the reason why for long series I chose to use those provided by the World Bank which are closer to the numbers in data bases from INEGI.

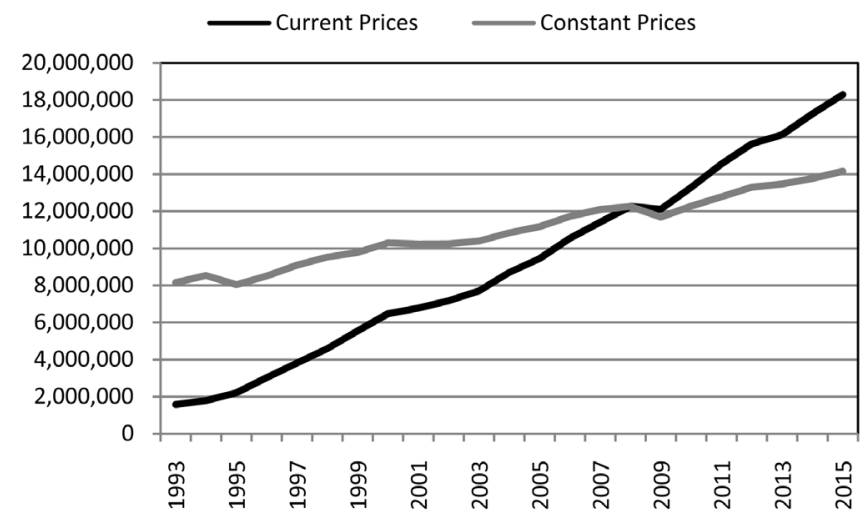

Figure 1. Mexico: GDP in Millions of Pesos. Source: Own elaboration with data from INEGI and author's estimation.

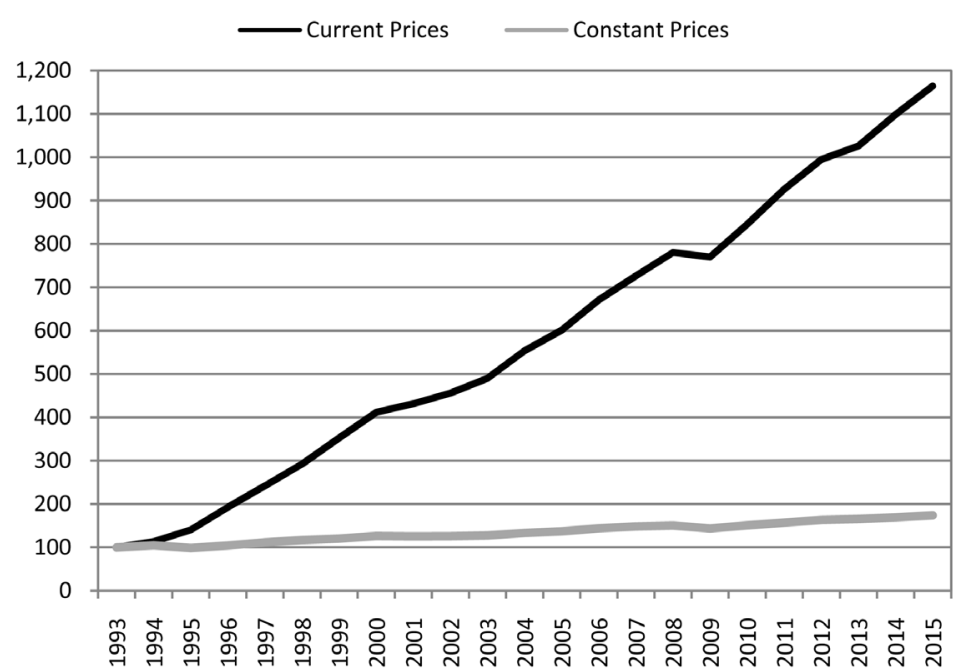

Figure 2. Mexico: GDP percentage variation $(1993=100)$. Source: Own elaboration and estimation with data from INEGI. 
Periods have not been chosen for their length but by the prevailing economic policy: from 1959 to 1970 was a time of closed economy of import substitution and fiscal equilibrium with low inflation; from 1971-1982 prevailed the closed economy but with expansionary fiscal policy and high inflation; from 1983 to 2000 the neoliberal model is established and begins the privatization of state enterprises and the openness to trade; from 2000 to 2015 began the political change after more than 70 years of monopoly of the Institutional Revolutionary Party (PRI) but continue extending neoliberal measures.

In the following table we see that in the period 1959-2015 the average real GDP growth was $4.02 \%$ per annum. However, if we divide it into historical periods the numbers change confirming trends pointed to the U.K. and the US from 1959 to 1970 — time of the so-called "Stabilizer Development" (Desarrollo Estabilizador)— real GDP grew annually at an average of 6.4\%. From 1971-1982, during expansionary and inflationary policies of the presidential administrations of Luis Echeverria and Jose Lopez Portillo, that number fell slightly to 6.27\%. During the administrations of Presidents Miguel de la Madrid, Carlos Salinas and Ernesto Zedillo, the application of neoliberal measures for indiscriminate trade liberalization, currency overvaluation, dismantling of a large number of state enterprises, foreign ownership of the banking system, etc. reduced even further the average growth which drops to2.61\%.

In the last period beginning in December 2000 with the change of political party in power in our country, the implementation of such neoliberal policies extends further and in the next 15 years the average annual real growth of our economy goes down to $2.13 \%$.

Let us see in Figure 3, the numbers from the Table 3.

\subsection{Real GDP per Capita}

Population

To get closer to the central theme-the research of real income per inhabitant we need to add the variable "Population". Production alone does not tell us anything about the average standard of living of a country as it

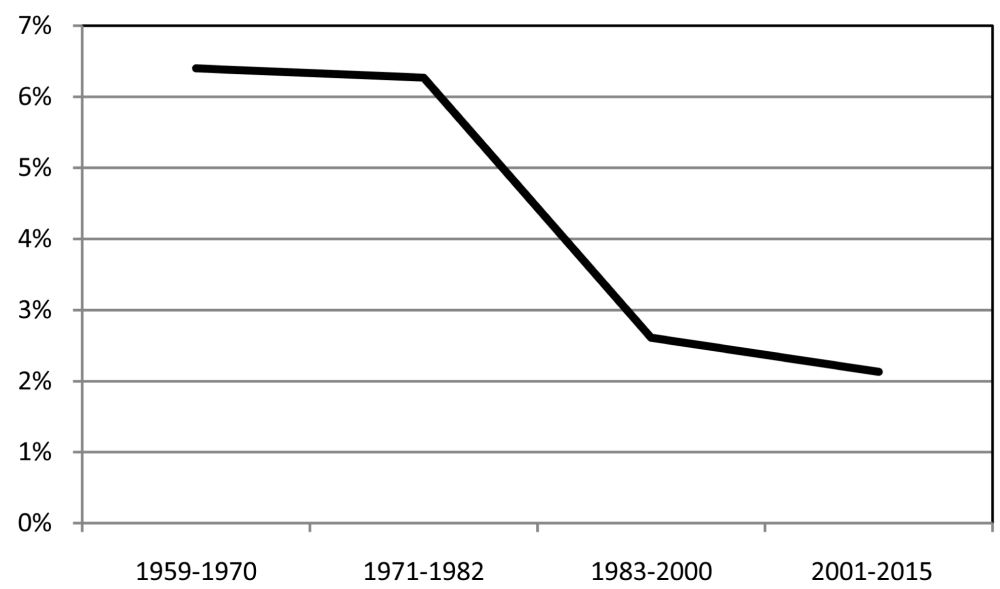

Figure 3. Mexico: Real GDP average annual growth through periods. Source: Own elaboration based on data from World Bank.

Table 3. Mexico: Real GDP average annual growth through periods. Source: Own elaboration based on data from World Bank.

\begin{tabular}{ccc}
\hline Period & \% growth \\
\hline $\mathbf{1 9 5 9 - 2 0 1 5}$ & $\mathbf{4 . 0 2 \%}$ \\
$1959-1970$ & $6.40 \%$ \\
$1971-1982$ & $6.27 \%$ \\
$1983-2000$ & $2.61 \%$ \\
$2001-2015$ & $2.16 \%$ \\
\hline
\end{tabular}


may have few or many inhabitants. Mexico's GDP is much higher than that of countries like Switzerland, though the latter has a higher standard of living than ours. It is necessary therefore to divide the GDP by the population. In that way we get the proportion of GDP that would correspond to each inhabitant if divided equitably, that is, in equal parts.

The population is counted every ten years and, therefore, in the intervening years are estimated based on trends. However, when comparing census and intercensal survey made in Mexico by INEGI, with those estimates made by other international organizations and the same INEGI, we found significant discrepancies. For example, the 2010 Census in our country gave a figure of 112,336,538 inhabitants but our statistical institute estimations made in the National Survey of Occupation and Employment give us the figure of 114,291,638, similar to that handling by the National Council of Population (CONAPO) [9] in their statistics. Mean while the World Bank estimated the population of our country in the year 2010 in 118,617,542 inhabitants and Penn World Table 8.1 gives a figure of 113,423,047 numbers that don't match with our census results.

In Table 4 we can see great differences in the numbers of World Bank, differences that will affect our estimation about real GDP per capita. United Nations is taking the numbers of CONAPO and so I will do.

The first thing that stands out in Table 5 is that even though our country is middle income, per capita GDP is equivalent to 116.930 pesos per year measured in constant pesos of 2008. In current 2015 pesos the per capita figure is 151,100 pesos.

Table 4. Mexico: population estimates and census and intercensal results Source: Own elaboration based on data from WB, IMF, UNO, CONAPO and INEGI.

\begin{tabular}{|c|c|c|c|c|c|}
\hline Year & WB & IMF & UNO & CONAPO & INEGI \\
\hline 1993 & $90,887,097$ & $91,605,000$ & $91,600,655$ & $91,600,655$ & - \\
\hline 1994 & $92,663,664$ & $93,059,000$ & $93,055,300$ & $93,055,300$ & - \\
\hline 1995 & $94,426,946$ & $94,495,000$ & $94,490,336$ & $94,490,336$ & $91,158,290$ \\
\hline 1996 & $96,181,710$ & $95,881,000$ & $95,876,664$ & $95,876,664$ & - \\
\hline 1997 & $97,925,825$ & $97,209,000$ & $97,204,604$ & $97,204,604$ & - \\
\hline 1998 & $99,632,299$ & $98,490,000$ & $98,485,424$ & $98,485,424$ & - \\
\hline 1999 & $101,266,570$ & $99,711,000$ & $99,706,067$ & $99,706,067$ & - \\
\hline 2000 & $102,808,590$ & $100,900,000$ & $100,895,811$ & $100,895,811$ & $97,483,412$ \\
\hline 2001 & $104,239,563$ & $102,127,000$ & $102,122,295$ & $102,122,295$ & - \\
\hline 2002 & $105,578,297$ & $103,423,000$ & $103,417,944$ & $103,417,944$ & - \\
\hline 2003 & $106,888,418$ & $104,725,000$ & $104,719,891$ & $104,719,891$ & - \\
\hline 2004 & $108,257,822$ & $105,956,000$ & $105,951,569$ & $105,951,569$ & - \\
\hline 2005 & $109,747,906$ & $107,156,000$ & $107,151,011$ & $107,151,011$ & $103,263,388$ \\
\hline 2006 & $111,382,857$ & $108,417,000$ & $108,408,827$ & $108,408,827$ & - \\
\hline 2007 & $113,139,374$ & $109,796,000$ & $109,787,388$ & $109,787,388$ & - \\
\hline 2008 & $114,972,821$ & $111,304,000$ & $111,299,015$ & $111,299,015$ & - \\
\hline 2009 & $116,815,612$ & $112,849,000$ & $112,852,594$ & $112,852,594$ & - \\
\hline 2010 & $118,617,542$ & $114,292,000$ & $114,255,555$ & $114,255,555$ & $112,336,538$ \\
\hline 2011 & $120,365,271$ & $115,685,000$ & $115,682,868$ & $115,682,868$ & - \\
\hline 2012 & $122,070,963$ & $117,055,000$ & $117,053,750$ & $117,053,750$ & - \\
\hline 2013 & $123,740,109$ & $118,397,000$ & $118,395,054$ & $118,395,054$ & - \\
\hline 2014 & $125,385,833$ & $119,715,000$ & $119,713,203$ & $119,713,203$ & - \\
\hline 2015 & $127,007,072 \mathrm{e}$ & $121,087,000$ & $121,005,815$ & $121,005,815$ & $119,938,473$ \\
\hline
\end{tabular}


Table 5. Mexico: Estimated real GDP per capita in Mexican pesos. Source: Own elaboration based on data from INEGI and CONAPO.

\begin{tabular}{|c|c|c|c|c|}
\hline Year & GDP at constant 2008 prices (Pesos) & Estimated population & Real GDP per capita Pesos) & Monthly real GDP by family \\
\hline 1993 & $8,132,915,150,000$ & $91,600,655$ & 88,787 & 36,994 \\
\hline 1994 & $8,517,386,950,000$ & $93,055,300$ & 91,530 & 38,138 \\
\hline 1995 & $8,026,897,225,000$ & $94,490,336$ & 84,949 & 35,396 \\
\hline 1996 & $8,498,458,775,000$ & $95,876,664$ & 88,639 & 36,933 \\
\hline 1997 & $9,090,197,200,000$ & $97,204,604$ & 93,516 & 38,965 \\
\hline 1998 & $9,517,603,875,000$ & $98,485,424$ & 96,640 & 40,267 \\
\hline 1999 & $9,771,439,625,000$ & $99,706,067$ & 98,002 & 40,834 \\
\hline 2000 & $10,288,981,700,000$ & $100,895,811$ & 101,976 & 42,490 \\
\hline 2001 & $10,226,682,450,000$ & $102,122,295$ & 100,142 & 41,726 \\
\hline 2002 & $10,240,173,300,000$ & $103,417,944$ & 99,017 & 41,257 \\
\hline 2003 & $10,385,857,075,000$ & $104,719,891$ & 99,178 & 41,324 \\
\hline 2004 & $10,832,003,975,000$ & $105,951,569$ & 102,235 & 42,598 \\
\hline 2005 & $11,160,492,600,000$ & $107,151,011$ & 104,157 & 43,399 \\
\hline 2006 & $11,718,671,725,000$ & $108,408,827$ & 108,097 & 45,040 \\
\hline 2007 & $12,087,601,950,000$ & $109,787,388$ & 110,100 & 45,875 \\
\hline 2008 & $12,256,863,475,000$ & $111,299,015$ & 110,126 & 45,886 \\
\hline 2009 & $11,680,749,350,000$ & $112,852,594$ & 103,504 & 43,127 \\
\hline 2010 & $12,277,658,825,000$ & $114,255,555$ & 107,458 & 44,774 \\
\hline 2011 & $12,774,242,725,000$ & $115,682,868$ & 110,425 & 46,010 \\
\hline 2012 & $13,287,534,000,000$ & $117,053,750$ & 113,517 & 47,299 \\
\hline 2013 & $13,466,299,500,000$ & $118,395,054$ & 113,740 & 47,392 \\
\hline 2014 & $13,769,333,825,000$ & $119,713,203$ & 115,019 & 47,925 \\
\hline 2015 & $14,120,020,875,000$ & $121,005,815$ & 116,689 & 48,620 \\
\hline
\end{tabular}

In Figure 4 we note that from 1993 to 2015 real GDP (calculated from base year 2008) grew 74\% but by subtracting the increase in population in the same period GDP per capita increased only $31 \%$. Once again the annual growth shows a smaller slope, or what is the same, a lower growth as we approach to the actual values that matter most to the population.

Table 6 shows the average annual growth rate of real per capita GDP reached in the period 1959-2015: 1.83\% per annum. When analyzed in each of the periods we observe its downward trend. From 1959 to 1970 the real grow this 3.26\% - the real GDP per capita would have doubled in 21 years if this rate had been preserve. From 1971 to 1982 , it was $3.4 \%$. From 1983 to 2000 it falls strongly to $0.58 \%-120$ years to double. From the so called political transition there is not a recovery according to the expectations of neoliberalism: $0.95 \%$ per annum, 74 years to double the standard of living or, what is the same, three generations.

\section{International Comparisons}

\subsection{Real GDP per Capita in US Dollars}

All figures in local currency are useful to study the evolution of our economy in local units of currency: an endogenous analysis. But they not are useful to make comparisons with other nations in which other currencies circulate. Therefore it has been established the practice of measuring in a currency that is an international reference: the US dollar. In Table 7 we see these figures. 
Table 6. Mexico: average increase in real GDP per capita in annual periods. Source: own elaboration with data from INEGI, World Bank and author's calculations.

\begin{tabular}{ccc}
\hline Period & Average annual rate & Years to duplicate \\
\hline $1959-2015$ & $1.83 \%$ & 38 \\
$1959-1970$ & $3.26 \%$ & 21 \\
$1971-1982$ & $3.40 \%$ & 21 \\
$1983-2000$ & $0.58 \%$ & 120 \\
$2001-2015$ & $0.95 \%$ & 74 \\
\hline
\end{tabular}

Table 7. Position of Mexico in the World according to their per capita GDP in dollars at current prices. 2014 data. Source: own elaboration with data from World Bank.

\begin{tabular}{|c|c|c|c|c|c|}
\hline Position & Country & GDP per capita & Position & Country & GDP per capita \\
\hline 1 & Luxembourg & $\$ 116,664$ & 33 & Bahamas & $\$ 22,217$ \\
\hline 2 & Norway & $\$ 97,307$ & 34 & Portugal & $\$ 22,132$ \\
\hline 3 & Qatar & $\$ 96,732$ & 35 & Greece & $\$ 21,498$ \\
\hline 4 & Switzerland & $\$ 85,594$ & 36 & Trinidad \& Tobago & $\$ 21,324$ \\
\hline 5 & Australia & $\$ 61,925$ & 37 & Estonia & $\$ 20,162$ \\
\hline 6 & Denmark & $\$ 60,707$ & 38 & Czech Republic & $\$ 19,530$ \\
\hline 7 & Suecia & $\$ 58,939$ & 39 & Oman & $\$ 19,310$ \\
\hline 8 & Singapore & $\$ 56,285$ & 40 & Equatorial Guinea & $\$ 18,918$ \\
\hline 9 & United States of America & $\$ 54,629$ & 41 & Slovakia & $\$ 18,501$ \\
\hline 10 & Irlanda & $\$ 54,374$ & 42 & Uruguay & $\$ 16,807$ \\
\hline 11 & Netherlands & $\$ 52,172$ & 43 & Lithuania & $\$ 16,507$ \\
\hline 12 & Iceland & $\$ 52,004$ & 44 & Latvia & $\$ 15,719$ \\
\hline 13 & Austria & $\$ 51,191$ & 45 & Seychelles & $\$ 15,543$ \\
\hline 14 & Canada & $\$ 50,235$ & 46 & Saint Kitts \& Nevis & $\$ 15,510$ \\
\hline 15 & Finland & $\$ 49,824$ & 47 & Barbados & $\$ 15,366$ \\
\hline 16 & Germany & $\$ 47,822$ & 48 & Chile & $\$ 14,528$ \\
\hline 17 & Belgium & $\$ 47,353$ & 49 & Poland & $\$ 14,343$ \\
\hline 18 & United Kingdom & $\$ 46,332$ & 50 & Hungary & $\$ 14,029$ \\
\hline 19 & United Arab Emirates & $\$ 43,963$ & 51 & Croatia & $\$ 13,475$ \\
\hline 20 & Kuwait & $\$ 43,594$ & 52 & Antigua \& Barbuda & $\$ 13,432$ \\
\hline 21 & France & $\$ 42,733$ & 53 & Russian Federation & $\$ 12,736$ \\
\hline 22 & Brunei Darussalam & $\$ 40,980$ & 54 & Kazakhstan & $\$ 12,602$ \\
\hline 23 & Hong Kong & $\$ 40,170$ & 55 & Argentina & $\$ 12,510$ \\
\hline 24 & Israel & $\$ 37,208$ & 56 & Panama & $\$ 11,949$ \\
\hline 25 & Japan & $\$ 36,194$ & 57 & Palau & $\$ 11,880$ \\
\hline 26 & Italy & $\$ 34,909$ & 58 & Brazil & $\$ 11,384$ \\
\hline 27 & Spain & $\$ 29,767$ & 59 & Malaysia & $\$ 11,307$ \\
\hline 28 & Korea, Republic of & $\$ 27,970$ & 60 & Gabon & $\$ 10,772$ \\
\hline 29 & Cyprus & $\$ 27,194$ & 61 & Turkey & $\$ 10,515$ \\
\hline 30 & Bahrain & $\$ 24,855$ & 62 & Costa Rica & $\$ 10,415$ \\
\hline 31 & Saudi Arabia & $\$ 24,161$ & 63 & Mexico & $\$ 10,326$ \\
\hline 32 & Slovenia & $\$ 23,999$ & & & \\
\hline
\end{tabular}




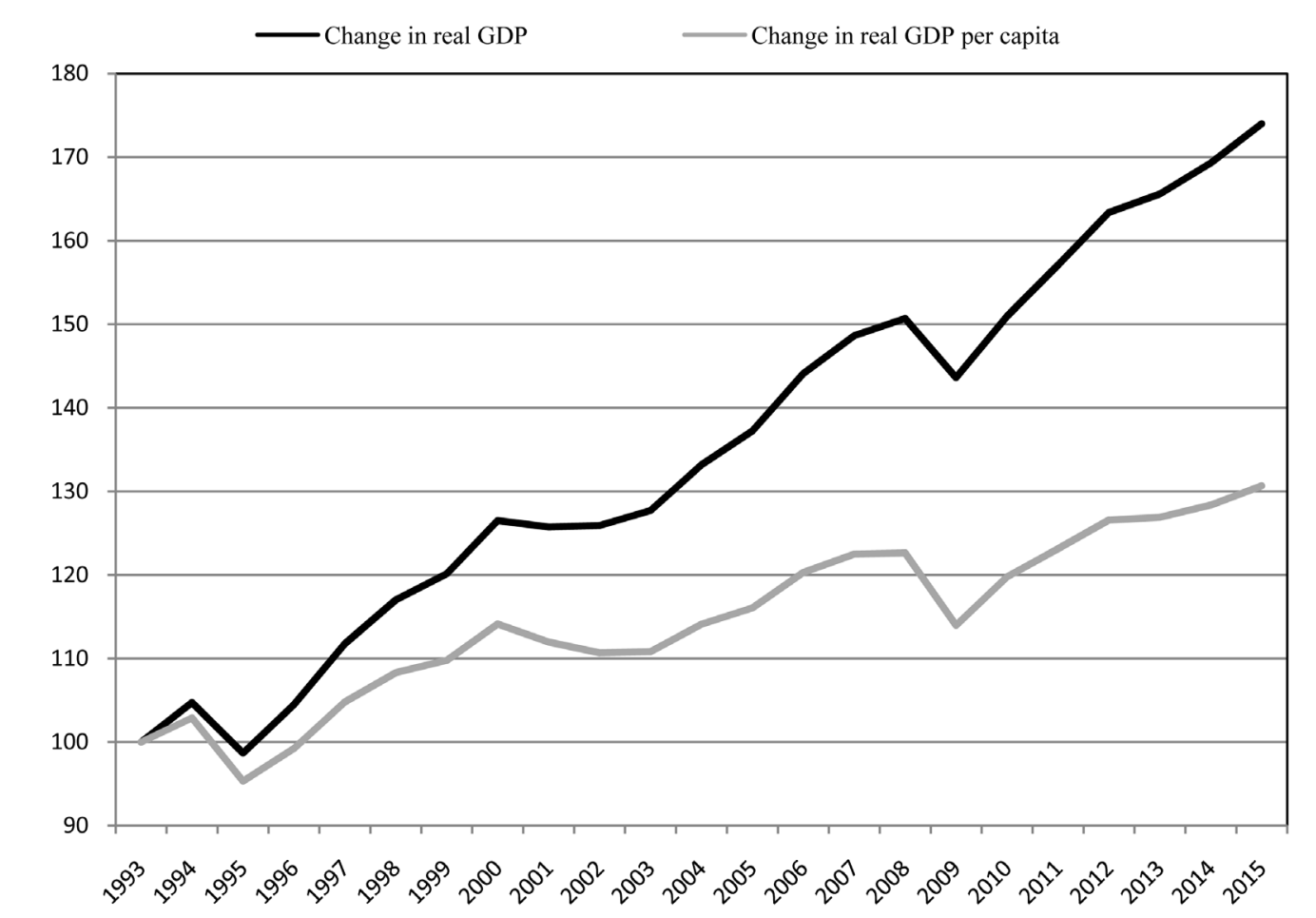

Figure 4. Mexico: percentage variations $(1993=100)$. Source: Own elaboration based on data from INEGI and CONAPO.

\subsection{International US Dollars}

Measuring GDP in dollars allows us to make international comparisons, but has the problem of omitting the different purchasing power measured by the goods that can be purchased with a dollar in each country, what is called the International Dollar that was first proposed by Roy C. Geary, an Irish statistician in 1958 and further developed and intensely promoted in the 1970s by Salem Hanna Khamis, a Palestinian economic statistician [10].

From those years started the development of the theory of what is called purchasing power parity (PPP) theory [11] and applying it to measuring GDP. Read the clear definition given by the World Bank on this issue:

"Purchasing power parity conversion factor is the number of units of a country's currency required to buy the same amounts of goods and services in the domestic market as U.S. dollar would buy in the United States. This conversion factor is for private consumption (i.e., household final consumption expenditure). For most economies PPP figures are extrapolated from the 2011 International Comparison Program (ICP) benchmark estimates or imputed using a statistical model based on the 2011 ICP. For 47 high- and upper middle-income economies conversion factors are provided by Eurostat and the Organization for Economic Cooperation and Development (OECD).” [12].

In 1968 the United Nations Organization (UNO) founded the International Comparison Program (ICP for its initials in English) and at the same time the American economist, Alan Heston joined it. In 1990he and Robert Summers formed the Center for International Comparisons (CIC) at the University of Pennsylvania and published a pioneering work (Summers and Heston, 1991 [13]). Immediately the International Monetary Fund, the World Bank and other major agencies incorporated in their statistics data converted to international dollars using the PPP.

The work of the CIC of the University of Pennsylvania was embodied in several editions: the PWT 6.1, 6.2, 6.3 and 7.1, etc. Today the University of Groningen in the Netherlands (Fenestra et al, 2015 [14]) has continued its publications with the PWT 8.0, 8.1 and they have announced for April 2015 the PWT 8.5 [15] with updated data up to 2014.

Table 8 shows us the list of countries with the highest per capita GDP measured in current PPP international dollars, data referrers to 2015 estimations by the IMF. We note that Mexico increases its real GDP per capita but moves to place 68 . It is interesting to see that some of the countries above us change radically its position. 
Table 8. Gross domestic product based on purchasing-power-parity (PPP) per capita GDP (Current international dollar). 2015 data. Source: own elaboration with data from International Monetary Fund.

\begin{tabular}{|c|c|c|c|c|c|}
\hline Position & Country Name & $\begin{array}{c}\text { PPP GDP per capita } \\
\text { (current international US\$) }\end{array}$ & Position & Country Name & $\begin{array}{l}\text { PPP GDP per capita } \\
\text { (current international US\$) }\end{array}$ \\
\hline 1 & Qatar & $143,532.45$ & 34 & Malta & $34,544.39$ \\
\hline 2 & Luxembourg & $93,173.61$ & 35 & Israel & $33,495.17$ \\
\hline 3 & Singapore & $85,198.16$ & 36 & Trinidad and Tobago & $32,654.34$ \\
\hline 4 & Brunei Darussalam & $72,370.45$ & 37 & Czech Republic & $30,895.37$ \\
\hline 5 & Kuwait & $70,913.56$ & 38 & Cyprus & $30,769.58$ \\
\hline 6 & Norway & $67,445.20$ & 39 & Slovenia & $30,508.29$ \\
\hline 7 & United Arab Emirates & $65,149.04$ & 40 & Slovak Republic & $29,209.56$ \\
\hline 8 & San Marino & $61,836.32$ & 41 & Lithuania & $28,210.27$ \\
\hline 9 & Switzerland & $58,730.92$ & 42 & Estonia & $27,994.86$ \\
\hline 10 & Hong Kong SAR & $56,428.07$ & 43 & Portugal & $27,624.23$ \\
\hline 11 & United States of America & $56,421.39$ & 44 & Equatorial Guinea & $26,810.26$ \\
\hline 12 & Saudi Arabia & $53,149.06$ & 45 & Greece & $26,773.37$ \\
\hline 13 & Bahrain & $52,514.68$ & 46 & Seychelles & $26,443.43$ \\
\hline 14 & Ireland & $51,119.00$ & 47 & Poland & $26,210.06$ \\
\hline 15 & Netherlands & $48,317.05$ & 48 & Hungary & $25,895.11$ \\
\hline 16 & Taiwan & $47,898.66$ & 49 & Malaysia & $25,631.55$ \\
\hline 17 & Australia & $47,607.70$ & 50 & The Bahamas & $25,576.90$ \\
\hline 18 & Sweden & $47,228.98$ & 51 & Latvia & $24,540.59$ \\
\hline 19 & Austria & $47,031.00$ & 52 & Kazakhstan & $24,359.64$ \\
\hline 20 & Germany & $46,895.97$ & 53 & Russia & $24,066.82$ \\
\hline 21 & Canada & $45,722.97$ & 54 & Gabon & $23,811.52$ \\
\hline 22 & Denmark & $45,451.27$ & 55 & Chile & $23,556.26$ \\
\hline 23 & Iceland & $45,268.94$ & 56 & Antigua and Barbuda & $22,965.79$ \\
\hline 24 & Belgium & $43,800.21$ & 57 & Argentina & $22,458.85$ \\
\hline 25 & France & $41,018.21$ & 58 & St. Kitts and Nevis & $21,585.49$ \\
\hline 26 & Finland & $40,838.37$ & 59 & Uruguay & $21,246.89$ \\
\hline 27 & United Kingdom & $40,676.48$ & 60 & Croatia & $21,169.43$ \\
\hline 28 & Oman & $40,538.85$ & 61 & Romania & $20,526.45$ \\
\hline 29 & Japan & $38,215.92$ & 62 & Panama & $20,418.01$ \\
\hline 30 & Korea & $36,601.07$ & 63 & Turkey & $20,188.41$ \\
\hline 31 & New Zealand & $36,151.81$ & 64 & Mauritius & $19,373.83$ \\
\hline 32 & Italy & $35,811.44$ & 65 & Lebanon & $18,422.45$ \\
\hline 33 & Spain & $34,899.40$ & 66 & Mexico & $18,369.50$ \\
\hline
\end{tabular}


Although international dollars for a single year are usually presented at the current year's exchange rates and current PPP adjustments, they may also be adjusted for inflation in order to represent currencies in constant (international) dollars for a base year, such as 2011 for example.

We should remark that PPP takes in consideration the difference between inflation in any country in relation with inflation in the USA. PPP at constant prices takes into consideration also the increase in prices in the international US Dollar establishing a base year, for example 2011 in World Bank Statistics.

In Figure 5 we compare the development of PPP GDP per capita at current and constant international US Dollars.

While GDP per capita, PPP at current international US\$ increased in Mexico 184.22\% from 1990 to 2014, at constant 2011 international US\$ Dollars did it only 29.88\% a poor average rate of $1.24 \%$ per year.

\section{Results}

Stand out in our writing the difficulties we have to face and solve before determining the numbers on which to base any research on living standards, income concentration and inequality within a country, as in the case of Mexico. These difficulties are associated with the different figures that we find in the databases of national and international organizations about GDP, population, inflation and the exchange rate that are critical to determining the real per capita GDP in both the local currency at constant prices and in constant US dollars.

The research conducted so far show that since the establishment of neoliberal policies in our country growth rates of real GDP and real GDP per capita, in any of their measures, declined as happened in highly developed countries.

In Table 6 we see that if we continue with those rates, it will take over 74 years to double the real GDP per capita with the intensification and accumulation of social tensions that will force changes in economic policy.

In Table 5 we read that the real per capita GDP in pesos in 2015 was \$ 116.930 and if we calculate it by average family of five members is equivalent to $\$ 48.721$ pesos per month. If we deduct from these figures those elements that are not consumption, even so we would be talking about an internal market with a higher purchasing power that the actual reality shows.

In the course of this investigation I had to overcome the difficulties encountered in bringing together the statistical information available. Clearly it is very difficult to analyze in Mexico periods of over 20 years due to lack of data of gross domestic product in homologated series, especially in the case of the estimated population of our country. In turning to international sources we also find significant discrepancies as in the case of the World Bank which have population series with a big difference to the estimates that I consider most appropriate. The same thing happened with the average exchange rate that that institution takes into their estimates of GDP per capita in dollars.

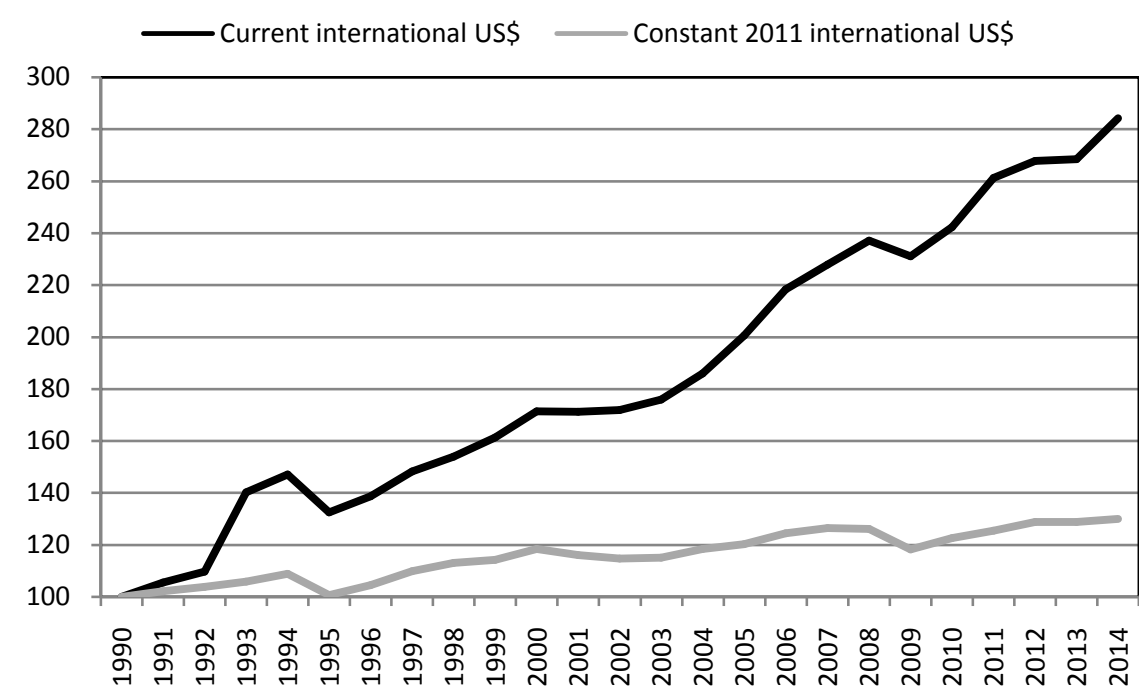

Figure 5. Mexico: GDP per capita, PPP; percentage variations $(1990=100)$. Source: own elaboration with data from World Bank. 
Years ago I read in an Italian magazine that we must be very careful when interpreting the statistical numbers as in the case, for example, that there are two people and a chicken on an island, statistically each islander would has half a chicken but we do not know whether one of them owns the animal and eats it alone.

We already have international consensus that there has been an increase inequality in recent decades and therefore in poverty in most countries. The logical question that should make us now is: What is the situation in Mexico?

We are forced to move to a second stage in our investigation which, already defined real GDP per capita, we can determine how national income is distributed within Mexico. In other words, who eats the chicken?

\section{References}

[1] Krugman, P. (1992) The Rich, the Right, and the Facts: Deconstructing the Income Distribution Debate. The American Prospect. Consulted January 2, 2016. http://prospect.org/article/rich-right-and-facts-deconstructing-inequality-debate

[2] Encinas Ferrer, C. (2009) Neoliberalismo y distribución del ingreso en los Estados Unidos de América. Revista Problemas del Desarrollo. Revista Latinoamericana de Economía, Instituto de Investigaciones Económicas, UNAM, 40, 13-32.

[3] Encinas Ferrer, C., Guzmán, G.R. and Morales, L.I.R. (2008) Un planeta y cuatro o cinco mundos: La polarización económica y su impacto en el empleo. en Los Rostros de la Pobreza, El Debate, Tomo V, Coord. Rocío Enríquez Rosas, Sistema Universitario Jesuita, Guadalajara.

[4] INEGI. National Institute of Statistics and Geography (INEGI). Sistema de Cuentas Nacionales de México, SCNM. Instituto Nacional de Estadística y Geografía. Banco de Información económica (BIE). Various consults between September 2015 and January 2016. http://www.inegi.org.mx/sistemas/bie/

[5] United Nations Statistics Division. Various Consults between September 2015 and January 2016. http://unstats.un.org/unsd/default.htm

[6] World Bank. Data. Consulted in Many Occasions between October 2015 and January 2016. http://datos.bancomundial.org/

[7] International Monetary Fund (IMF). Report for Selected Countries and Subjects. Various Consults between September 2015 and January 2016. http://www.imf.org/external/data.htm

[8] Aparicio Cabrera, A. (2011) Series estadísticas de la economía mexicana en el siglo XX. Economía Informa, julioagosto 2011/núm. 369. UNAM, México. Consulted December 15, 2015. http://www.economia.unam.mx/publicaciones/econinforma/369/06abrahamapariciocabrera.pdf.

[9] Consejo Nacional de Población (CONAPO) (National Council of Population). Proyecciones de Población. Various Consults between September 2015 and January 2016. http://www.conapo.gob.mx/es/CONAPO/Proyecciones.

[10] Business Encyclopedia. https://www.business-case-analysis.com/international-dollar.html

[11] Investopedia. Consulted, February 18, 2016. http://www.investopedia.com/terms/p/ppp.asp\#ixzz40Xa6R6D4.

[12] World Bank, PPP Conversion Factor, Private Consumption (LCU per International \$). http://data.worldbank.org/indicator/PA.NUS.PRVT.PP

[13] Summers, R. and Heston, A. (1991) The Penn World Table (Mark 5): An Expanded Set of International Comparisons, 1950-1988. Quarterly Journal of Economics, 106, 327-368. http://dx.doi.org/10.2307/2937941

[14] Feenstra, R.C., Inklaar, R. and Timmer, M.P. (2015) The Next Generation of the Penn World Table. Forthcoming American Economic Review. www.ggdc.net/pwt

[15] University of Groningen. PWT 8.1. Consulted in Many Occasions between October 2015 and January 2016. http://www.rug.nl/research/ggdc/data/pwt/pwt-8.1. 